\title{
How Does an Invasive Cyprinid Benefit from the Hydrological Disturbance of Mediterranean Temporary Streams?
}

\author{
Paula Matono ${ }^{1,2}$, Janine da Silva ${ }^{2}$ and Maria Ilhéu ${ }^{1,2, *}$ \\ 1 Instituto de Ciências Agrárias e Ambientais Mediterrânicas (ICAAM), Universidade de Évora, \\ Núcleo da Mitra, apartado 94, 7006-554 Évora, Portugal; pmatono@uevora.pt \\ 2 Departamento de Paisagem, Ambiente e Ordenamento, Escola de Ciências e Tecnologia, \\ Universidade de Évora, Rua Romão Ramalho 59, 7000-671 Évora, Portugal; janine@uevora.pt \\ * Correspondence: milheu@uevora.pt; Tel.: +351-266-740-800
}

Received: 18 December 2017; Accepted: 5 June 2018; Published: 13 June 2018

\begin{abstract}
The Iberian Peninsula has been subjected to numerous fish introductions and the colonization of new areas by non-native species is constantly reported. However, there is a lack of knowledge about many aspects of the bio-ecology of these species and their invasive success within the environmental context of Mediterranean temporary rivers. This study aimed to address the following questions: (i) what are the main regional and local environmental drivers influencing fish assemblages and differentiating native from non-native species, particularly A. alburnus?; (ii) what are the environmental and anthropogenic disturbance factors responsible for the occurrence and abundance of A. alburnus?; (iii) is there a pattern in the spatiotemporal distribution of A. alburnus size classes, along the tributaries of reservoirs where the species occurs? Data on fish species, environmental variables, and anthropogenic disturbance were collected in 77 sites of the Guadiana and Sado river basins in the south of Portugal. Additionally, a seasonal sampling was performed along an upstream-downstream gradient of several tributaries from three reservoirs in these river basins. A multivariate analysis and a multi-model approach were used in data analyses. Native and non-native fish assemblages showed different environmental drivers and responses to anthropogenic disturbance levels, though A. alburnus has revealed similarities with native species. The occurrence of $A$. alburnus was mainly determined by hydrological and morphological disturbances driven by anthropogenic activities. Furthermore, this species apparently performed seasonal movements along the tributaries of several reservoirs, profiting from these lentic habitats as a stepping-stone for further invasions. This study highlighted the wide ecological plasticity of A. alburnus, as it benefits from the anthropogenic hydrological disturbance (induced by reservoirs), and is also able to cope with the natural hydrological disturbance (resulting from the intermittency of these streams), to guarantee and enhance its invasive success in Mediterranean intermittent streams. It also gives a sound contribution to understand the spread of A. alburnus in these vulnerable freshwater ecosystems, and to delineate management measures, namely by identifying critical points in the river network along with prioritizing river restoration measures that benefit native species.
\end{abstract}

Keywords: Alburnus alburnus; spread; invasibility; hydrological disturbance; anthropogenic pressure; intermittent streams

\section{Introduction}

Mediterranean-climate streams, particularly the temporary ones, are naturally subject to high hydrological variability at seasonal and inter-annual scales [1]. Flow is one of the most important determinants of ecological patterns and processes in rivers [2-4], playing an important role in 
structuring fish assemblages in these streams [5-7]. The natural hydrological disturbance that characterizes these streams is disadvantageous for non-native species, thus decreasing the pressure on the native ones, which are adapted to this variability [8,9].

Additionally, freshwater ecosystems in Mediterranean regions have a long history of intense anthropogenic disturbances and continue to face mounting pressures from growing human populations and water impoundments $[10,11]$. The resulting water quality degradation and hydromorphological alterations increase the likelihood of the establishment and spread of non-native fishes [12-14], and account for their abundance in many areas $[5,15,16]$. Therefore, these regions are hotspots both of endemisms and freshwater fish introductions [17]. In fact, the number of non-native fishes exceed the number of endemic native fishes in each of the five Mediterranean-climate regions of the world [18], leading to the homogenization of the freshwater biota [18-20].

Biological invasions, coupled with habitat degradation, are considered one of the leading threats to native fish biodiversity in Mediterranean-climate streams [21]. Several types of adverse ecological impacts have been associated with freshwater fish invasions, operating across multiple levels of biological organization: genetic (gene transcription, hybridization); individual (behavior, morphology, vital rates); population (transmission of parasites/diseases, demographic effects, distributional effects); community (species extirpations, compositional changes, alterations in food webs); and ecosystem (biochemical cycles, energy fluxes between ecosystems, ecological engineering) levels [22,23].

Over the past decades, the Iberian Peninsula has been subject to numerous fish introductions and the colonization of new areas by non-native species is constantly reported [24,25]. The bleak, Alburnus alburnus (Linnaeus, 1758) is a freshwater cyprinid, native in many central European river basins [26]. This species was firstly detected in the Iberian peninsula in 1992 [27], where it has been introduced by anglers as a forage species for sport fish [28,29]. It rapidly spread afterwards and occurs presently in many river basins [26,30], representing a source of potential impacts on native species [23]. The successful expansion of this invasive species seems to be related to hydrological alterations in streams, since it is associated with river systems with dams [30]. The resulting lentic conditions possibly facilitated the establishment of A. alburnus, as in its original distribution area it occupies slow water habitats [31].

Although A. alburnus is considered limnophilic [26], it has successfully invaded lotic environments, and is found at great distances from the reservoirs where it was introduced [32]. This species reaches high abundances under different habitat conditions and is able to change its life cycle characteristics when introduced into new habitats and confronted with scenarios of environmental variability [33], demonstrating high ecological plasticity and adaptability to the natural hydrological variability of Mediterranean temporary streams [32]. However, like for most invasive species, there is a lack of knowledge about many aspects of its bio-ecology and invasiveness within the environmental context of Mediterranean temporary rivers.

Assessing the adaptive strategies that invasive species may use to colonize new invaded areas is a critical step to evaluate likely threats to the native fish fauna and to prevent their spread, which is often easier than controlling or eradicating large established populations [34]. This study aimed to analyze the distribution patterns of A. alburnus in temporary streams of southern Portugal, considering the underpinning environmental and anthropogenic factors, thus contributing to fill knowledge gaps on the invasion and adaptive strategies of this species in Mediterranean temporary rivers. Thus, the following questions were addressed: (i) what are the main regional and local environmental drivers influencing fish assemblages and differentiating native from non-native species, particularly A. alburnus?; (ii) what are the environmental and anthropogenic disturbance factors responsible for the occurrence and abundance of $A$. alburnus?; (iii) is there a pattern in the spatiotemporal distribution of A. alburnus size classes, along the tributaries of reservoirs where the species occurs? This information is fundamental to delineate measures intending to limit the dispersion of A. alburnus, and to minimize its potential impacts upon the native fish populations and freshwater ecosystems. 


\section{Materials and Methods}

\subsection{Study Area}

Study sites were located in intermittent streams of the Guadiana and Sado river basins, two of the main rivers in the south of Portugal. This is a lowland region with few low altitude mountains, registering a high mean annual air temperature of $16^{\circ} \mathrm{C}$ and a mean annual precipitation of $550 \mathrm{~mm}$ [35]. The climate is typically Mediterranean, with high intra and inter-annual variability of precipitation and flow, unpredictable floods between autumn and spring (October-March) and severe summer droughts (June-September) [36]. Sampled streams are naturally subjected to extreme environmental conditions during the dry season, when the flow ceases and large extensions of the streambed can dry up or become reduced to isolated pools, which are the only refuge for the fish fauna until rewetting and reestablishment of the fluvial continuity in the following autumn-winter [9].

Human activity in this region is mainly associated with agro-forestry (olive groves, vineyards, cereal production, and cork extraction) and livestock production, which are responsible for the largest proportion of water demands in the river basins (more than 80\%) [37]. Therefore, the principal anthropogenic pressures upon rivers are diffuse agricultural pollution and organic loading, channelization and water abstraction, which have led to significant water scarcity and quality problems, as well as habitat degradation [38]. The irregularity of the annual precipitation and the increasing water demand resulted in the construction of numerous reservoirs in southern Portuguese river basins, namely in Guadiana $(\mathrm{N}=29)$ and Sado $(\mathrm{N}=22)$ [39]. All these factors are responsible for major changes in aquatic ecosystems, threatening the native fish fauna [38,40].

Fish assemblages in the region have relatively low species richness but include many endemic species with high conservation status [41,42]. Native species are dominated by cyprinids that are rapidly declining due to anthropogenic impacts, including non-native introductions [43].

\subsection{Fish Sampling and Data Collection}

Fish sampling took place during the spring of 2015 and 2016 at 57 sites in several sub-basins of the Guadiana river (Figure 1): Caia $(\mathrm{N}=8)$, Xévora $(\mathrm{N}=6)$, Degebe $(\mathrm{N}=6)$, Lucefécit $(\mathrm{N}=1)$, Álamo $(\mathrm{N}=1)$, Ardila $(\mathrm{N}=7)$, Chança $(\mathrm{N}=4)$, Carreiras $(\mathrm{N}=2)$, Vascão $(\mathrm{N}=10)$, Foupana $(\mathrm{N}=6)$, and Odeleite $(\mathrm{N}=6)$. These data were supplemented with information collected in a previous research project conducted in the University of Évora between 2010 and 2012 [44] covering 20 more sites of several sub-basins of the Guadiana (Caia $(\mathrm{N}=2)$, Xévora $(\mathrm{N}=1)$, Degebe $(\mathrm{N}=9)$, Ardila $(\mathrm{N}=3)$, and Vascão $(\mathrm{N}=1))$ and Sado (Xarrama $(\mathrm{N}=1)$ and Alcáçovas $(\mathrm{N}=3)$ ) rivers, in a total of 77 sites. Each of these sites were sampled only once over the study years.

Additionally, in order to analyze the spatiotemporal variability of A. alburnus captures in river networks shaped by reservoirs, a seasonal sampling was carried out in the spring, summer, and autumn of 2015 and 2016 in several sites from two streams of the Degebe $(\mathrm{N}=3)$ and Caia $(\mathrm{N}=6)$ sub-basins in the Guadiana river (Figure 1). These data were also complemented with information collected in the previously mentioned research project [44], in sites from two more streams of Degebe $(\mathrm{N}=2)$ and Alcáçovas $(\mathrm{N}=3)$ sub-basins in the Guadiana and Sado rivers (Figure 1). The four streams sampled are tributaries of the Caia, Alqueva, and Pego do Altar reservoirs, all associated with large dams constructed mainly for public and agricultural supply, covering flood areas of 655 ha, 1970 ha and 25,000 ha, respectively, and registering average maximum and minimum flood levels between approximately $126 \mathrm{~m}$ and $133 \mathrm{~m}$ [39]. The sites sampled in each tributary sought to cover an upstream-downstream gradient, to the confluence with the respective reservoir (Figure 1). In all cases, the downstream sector suffers the influence of the reservoir, being located between $1000 \mathrm{~m}$ and $3100 \mathrm{~m}$ (at an average distance of $1700 \mathrm{~m}$ ) from the reservoir's lake. 


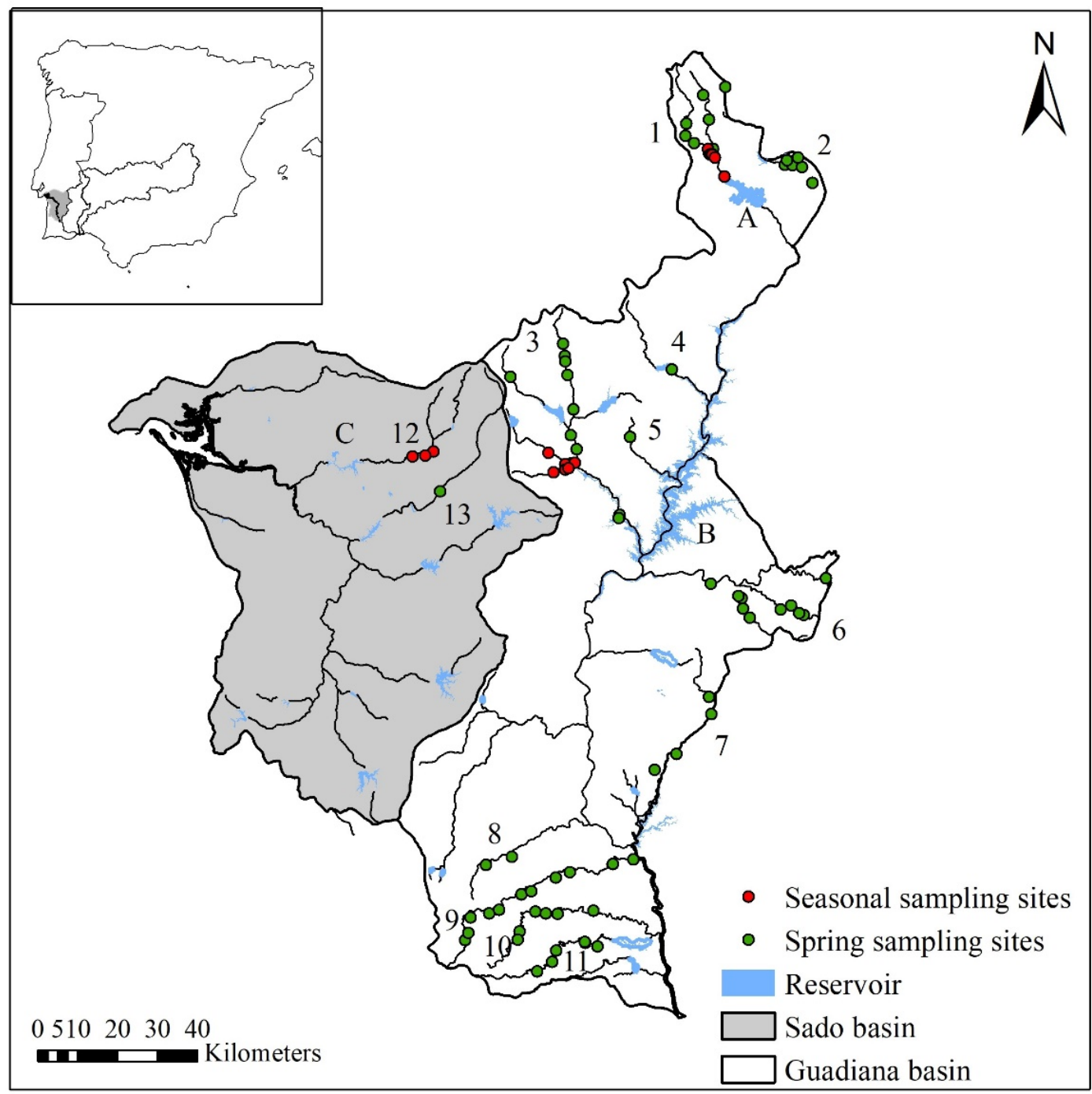

Figure 1. Location of the sites sampled during 2010-2012 and 2015-2016 in the Guadiana and Sado river basins in the south of Portugal. Sites are coded with different colors, according to the sampling approach: spring samples (green) and seasonal samples performed in spring, summer, and autumn (red). Sub-basins are identified with numbers: Caia (1), Xévora (2), Degebe (3), Lucefécit (4), Álamo (5), Ardila (6), Chança (7), Carreiras (8), Vascão (9), Foupana (10), Odeleite (11), Alcáçovas (12), Xarrama (13). Reservoirs mentioned in the text are identified with capital letters: Caia reservoir (A), Alqueva reservoir (B), Pego do Altar reservoir (C).

Spring and autumn samplings were carried out in flowing water conditions following the official protocol established for the fish fauna [45] under the implementation of the Water Framework Directive [46]. At each site, a reach with a length 20 times larger than the mean stream width, and a maximum of $150 \mathrm{~m}$, was defined, in order to include all the existing mesohabitats (pool, run, and riffle). Summer samplings were undertaken during the dry period, in isolated pools found within the stream reach defined at each site. Fish were captured with a single-pass using backpack battery-powered electrofishing equipment (IG 200/2B, PDC Hans-Grassl GmbH, Schonau am Konigssee, Germany), wading in shallow areas $(<1.2 \mathrm{~m})$ or from a boat in deeper areas, starting at the downstream edge of each reach. Captured individuals were identified at the species level and measured (total length, $\mathrm{TL}, \mathrm{mm}$ ). Individuals of native species were returned alive to the water whereas individuals of non-native species were removed and euthanized by thermal shock (freezing), in compliance with the Portuguese legislation and following the ethical guidelines of the Directive 2010/63/EU on animal 
welfare [47]. Complementary data from 2010-2012 were collected in the same periods of the year, following the same sampling methods and therefore comparable with data collected in 2015 and 2016. The necessary fishing permits were provided by the National Institute for the Conservation of Nature and Forests (ICNF).

The environmental characterization of the sampling sites was based on regional and local variables. The regional variables included altitude $(\mathrm{m})$, slope (\%), mean annual temperature (C), mean annual precipitation $(\mathrm{mm})$, mean annual runoff $(\mathrm{mm})$, stream order, drainage area of the basin upstream of the site $\left(\mathrm{km}^{2}\right)$, and distance from source at the sampled site $(\mathrm{km})$. Temperature, precipitation, and runoff were obtained from 30-year data series [39]. Topographical variables were derived from a Digital Elevation Model (DEM), with a 90-m grid cell resolution (CGIAR-CSI), using ArcGIS Desktop 10.5. The local variables were evaluated in situ at each site: (i) one measure was taken for water temperature $\left({ }^{\circ} \mathrm{C}\right)$, conductivity $\left(\mu \mathrm{S} \cdot \mathrm{cm}^{-1}\right), \mathrm{pH}$, and dissolved oxygen $\left(\mathrm{mg} \cdot \mathrm{L}^{-1}\right)$ using a multiparameter probe (WTW Multiline 340i), as well as for water turbidity (m) with a secchi disk; (ii) proportion of aquatic vegetation cover (hydrophytes, helophytes and woody debris), shadow and mesohabitat types (pool, run and riffle) were assessed through visual estimation; (iii) mean water depth $(\mathrm{m})$ and mean current velocity $\left(\mathrm{m} \cdot \mathrm{s}^{-1}\right)$ were measured with a graduated stick and an electromagnetic flow meter (Valeport Model 801), respectively, along transverse transects at regular distances, and a final mean value was calculated; (iv) the dominant substrate class (adapted from the Wentworth scale [48]: 1- mud and sand; 2- gravel; 3- pebble; 4- cobble; 5 - boulders; 6 - boulders larger than $50 \mathrm{~cm}$ ) was evaluated based on the weighted average of the observed classes.

At each site, the anthropogenic pressure level was also evaluated based on 10 variables originally developed in the scope of the EU project FAME [49] (Table A1): land use, urban area, degradation of riparian vegetation, longitudinal connectivity of the river segment, sediment load, hydrological regime, morphological condition, presence of artificial lentic water bodies, toxicity and acidification levels, and organic contamination/nutrient enrichment. Each variable was scored between 1 (absence of disturbance) and 5 (maximum disturbance). The sum of all scores represented the total anthropogenic pressure at each site. According to the total value obtained, the sites were classified into three classes of anthropogenic disturbance (following [50], based on the Refcond Guidance Document [51]: least disturbed-class 1 (total pressure lower than 14), moderately disturbed — class 2 (total pressure between 14 and 22), most disturbed-class 3 (total pressure higher than 22). Several physicochemical parameters complemented and supported the evaluation of the anthropogenic disturbance (mainly organic/nutrient enrichment): five day biological oxygen demand- $\mathrm{BOD}_{5}\left(\mathrm{mg} \cdot \mathrm{L}^{-1}\right)$, orthophosphate- $\mathrm{PO}_{4}{ }^{3-}\left(\mathrm{mg} \cdot \mathrm{L}^{-1}\right)$, nitrite $-\mathrm{NO}_{2}{ }^{-}$ $\left(\mathrm{mg} \cdot \mathrm{L}^{-1}\right)$, nitrate $-\mathrm{NO}_{3}{ }^{-}\left(\mathrm{mg} \cdot \mathrm{L}^{-1}\right)$, ammonium $-\mathrm{NH}_{4}{ }^{+}\left(\mathrm{mg} \cdot \mathrm{L}^{-1}\right)$, total suspended solids $\left(\mathrm{mg} \cdot \mathrm{L}^{-1}\right)$ and chlorophyll $a\left(\mathrm{mg} \cdot \mathrm{L}^{-1}\right)$ (monochromatic method described by [52]). At each site one water sample was collected prior to fish sampling. Laboratory analyses were undertaken according to the Standard Methods for the Examination of Water and Wastewater [53].

\subsection{Data Analysis}

The captures were standardized for an area of $100 \mathrm{~m}^{2}$ and expressed in terms of density (number of individuals $100 \mathrm{~m}^{-2}$ ). Data analysis was carried out separately for two data sets: (i) Spring samplings in a wide network of sites from the Guadiana and Sado river basins under lotic conditions; (ii) Seasonal samplings in four intermittent tributaries of different reservoirs registering high abundance of A. alburnus in the Guadiana and Sado river basins, covering an upstream-downstream gradient in three periods of the year (spring, summer, autumn), thus considering both lotic and lentic conditions. In this case, to ensure the comparability of data collected under different conditions between spring/autumn (flowing water and longitudinal continuity) and summer (isolated pools) and with different fishing efficiencies, the relative abundances of fish species were calculated and used in the statistical analysis. 


\subsubsection{Spring Samples}

To examine the relationships between fish species, environmental variables, and anthropogenic disturbance level, a Redundancy Analysis (RDA) [54] was used. A linear ordination method was selected after a preliminary Detrended Correspondence Analysis had shown a gradient length smaller than 3 SD [55]. A stepwise forward selection of the variables was used and the final model was tested with the Monte Carlo test under 999 permutations. Correlations higher than $|0.4|$ were used in gradients interpretation. The level of anthropogenic disturbance was also included in the analysis by creating a triplot ordination diagram where the sampling sites were coded according to the disturbance classes defined above. To account for multicollinearity, variables were maintained in the models only if their addition did not cause any Variation Inflation Factor (VIF) to exceed the value of 3. Species with a frequency of occurrence smaller than $2 \%$ were not considered for this analysis, since the relationship between these species and the variables could lack reliability, reflecting only occasional occurrences.

Univariate Generalized Linear Models (GLMs) were used for partitioning the variance [56] among environmental and anthropogenic disturbance variables (predictive variables) on the occurrence and abundance of $A$. alburnus (response variables). The set of environmental variables included altitude, mean annual runoff, drainage area of the basin, stream order, slope, mean annual temperature, mean annual precipitation, mean water depth, mean stream width, mean current velocity, dominant substrate class, proportion of each habitat type, $\mathrm{pH}$, dissolved oxygen, turbidity, and conductivity. The set of anthropogenic disturbance variables included the 10 variables mentioned above and evaluated at each site (Table A1). Although some environmental variables can be affected and reflect the anthropogenic disturbance of the sites, they do not allow to identify clearly the type of human-induced pressure involved or causing the disturbance, and for that reason they were not considered in the anthropogenic set. Models were performed using the Binomial distribution and logit link function for occurrence data (presence-absence), while the Poisson distribution and log link function were used for abundance data (density). For each response variable, three types of models were generated using the predictive variables: (i) including only environmental variables; (ii) including only anthropogenic disturbance variables; (iii) including a combination of both. The procedure considered all the possible combinations of the predictive variables and model selection was based on the Akaike's information criterion (AIC) to identify the best models in explaining both response variables. The best models were those with $\triangle \mathrm{AIC}$ values $\leq 4$ (difference of AIC between each model and the best model). The best global model would be chosen if an Akaike weight (wAIC) $>0.9$ was achieved (probability of being the best model), otherwise model averaging was applied to the models presenting an Akaike weight sum (wAIC) $>0.9$, in order to obtain the best average parameter estimates across variables [57]. In the end, the relative importance of the predictive variables was also computed. The proportional contribution of factors and overlaps to the total variation explained by the best models was then calculated [58]. The existence of over-dispersion in data (variance higher than the mean; dispersion parameter $>1$ ) was checked during the analyses. Multicollinearity between predictors was assessed with Spearman rank correlation and variance inflation factors (VIF), so that predictive variables were considered correlated if they presented values of $|\mathrm{r}|>0.5(p<0.05)$ and VIF $>3[59]$ and, in these circumstances, one of them was eliminated. This elimination decision took into account the potential ecological relevance of the variable and the goodness-of-fit of the models (AIC) when different correlated variables were included separately.

\subsubsection{Seasonal Samples}

Considering the longevity of A. alburnus [60] and the possible bioecological implications over different life cycle stages, size classes were established based on the frequency distribution of lengths. This method allows the decomposition of multimodal frequency distribution samples into normal distribution subgroups representing the age groups (cohorts) [61]. The Sturges' Rule [62,63] was applied to define the number of classes, using a total of 5021 A. alburnus individuals (total length between $20 \mathrm{~mm}$ and $250 \mathrm{~mm}$ ) captured between 2007 and 2016 by M. Ilhéu (University of Évora (Portugal) unpublished data) in the course of several research projects. The histogram produced 
(Figure S1) allowed the identification of 5 size classes, but the larger classes were merged due to the low number of captures, thus totaling 4 size classes considered for analysis: $\leq 60 \mathrm{~mm}$ (class 1 , young-of-the-year), 60-120 mm (class 2), 120-150 mm (class 3), and 150-200 mm (class 4).

Permutational multivariate analysis of variance (PERMANOVA) [64] was used to evaluate significant differences in the spatiotemporal variability of the relative abundance of the various size classes of $A$. allburnus, using the Monte Carlo test under 999 permutations. The river sector (upstream, intermediate, and downstream) and the period of the year (spring, summer, and autumn) were used as factors in this analysis. The river sector was assigned to each site based on the respective stream order and distance to the source.

Statistical analyses were carried out using the software Statistica 10.0, Primer 6.0, and Canoco 4.5. GLMs and variance partitioning were performed in the R software [65] using the packages "car" [66], "MuMin" [67], and "modEVA" [58]. Prior to analyses, species data were logged $(x+1)$ and environmental data were normalized [68]. The significance level was set at 0.05 .

\section{Results}

\subsection{Fish Species, Environmental Factors, and Anthropogenic Disturbance}

A total of 24 fish species were captured, including 15 native and 9 non-native species. Native species were the only species captured in $17 \%$ of the sampled sites, whereas non-native species totally dominated the captures in $8 \%$ of the sites. In the Guadiana river basin, 14 native species were recorded, representing $70 \%$ of the mean density per site $\left(25.4 \pm 39.2 \mathrm{ind} \cdot 100 \mathrm{~m}^{-2}\right)$, and 9 non-native species, representing $30 \%$ of the mean density per site $\left(15.6 \pm 45.6\right.$ ind $\left.\cdot 100 \mathrm{~m}^{-2}\right)$. Conversely, in the Sado river basin, a total of 3 native species were captured, which represented $10 \%$ of the mean density per site ( $3.6 \pm 7.2$ ind $\left.\cdot 100 \mathrm{~m}^{-2}\right)$, and 6 non-native species, representing $90 \%$ of the mean density per site $\left(19.5 \pm 40.1\right.$ ind $\left.\cdot 100 \mathrm{~m}^{-2}\right)$.

The first two axes of the RDA accounted for $30 \%$ of the total data variability (Figure 2). Nevertheless, these axes revealed a good association between the abundance of species and the relevant environmental variables ( 0.76 and 0.51 , respectively), explaining most of the species-environmental relation $(75 \%)$, thus supporting the interpretation of the results. Eleven significant variables $(p<0.05)$ were included in the ordination model. According to the canonical coefficients and inter-set correlations, axis 1 was mainly defined by depth $(r=0.52)$, proportion of riffles $(r=-0.43)$, dominant substrate class $(\mathrm{r}=-0.40)$, and mean annual runoff $(\mathrm{r}=-0.40)$. Axis 2 was related with the proportion of runs $(r=-0.43)$ and stream order $(r=-0.40)$. The ordination diagram (triplot of sites $\times$ species $\times$ environmental variables) showed a good spatial segregation of sites and species, especially along the first axis (Figure 2). This axis reflected an anthropogenic pressure gradient, especially discriminating the least disturbed sites and despite the considerable overlap of moderately disturbed and very disturbed sites. Along this same axis, results also evidenced an environmental gradient from headwaters to lowland streams, expressed mainly by regional scale variables such as stream order, altitude, and runoff. Some local variables strongly associated with the main variables of regional scale were also of particular importance, namely depth, substrate, aquatic cover and percentage of flowing water habitat types.

The output of the RDA analysis clearly distinguished two groups of species associated with the environmental gradients: (i) the group of native species that were primarily associated with less disturbed sites, particularly those located in headwater streams, with higher runoff, coarser substrate, habitat diversity and availability of runs and riffles; (ii) the group of non-native species, more abundant in lowland disturbed streams, with higher stream order, lower runoff and higher percentage of aquatic cover and deeper, lentic habitats, in which A. alburnus is included (Figure 2). Nevertheless, it is important to note that from all the captured non-native species, A. alburnus maintains a close proximity to the native species, namely Pseudochondrostoma willkommii Steindachner, 1866, 
Luciobarbus microcephalus Almaça, 1967, and Salaria fluviatilis (Asso, 1801), all of which were associated with flowing water habitats, such as runs, with high percentage of woody debris.

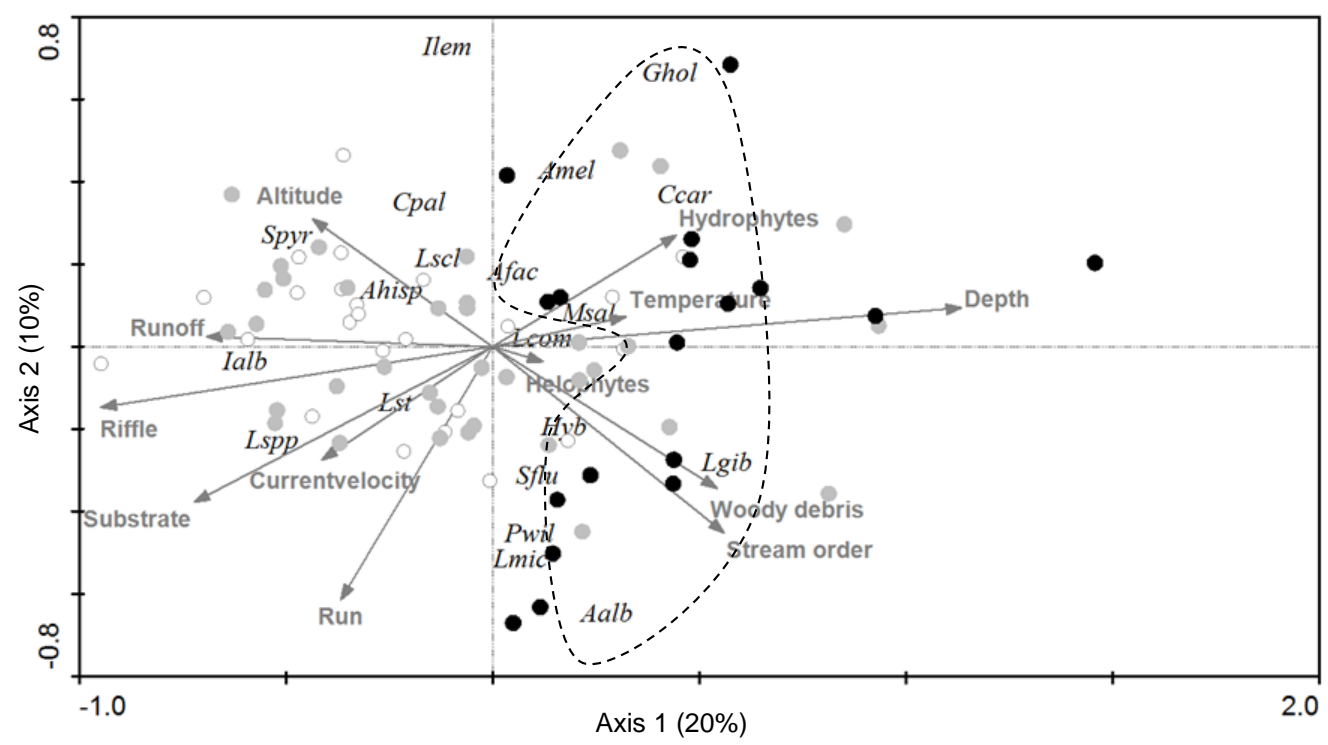

Figure 2. Ordination diagram (triplot) of the Redundancy Analysis between fish species and environmental variables (both regional and local). Sampling sites are coded according to the classes of anthropogenic disturbance level defined: least disturbed (white dots), moderately disturbed (grey dots) and most disturbed (black dots). Species abbreviations: Anaecypris hispanica (Ahisp), Iberocypris alburnoides (Ialb), Iberocypris lemmingii (Ilem), Squalius pyrenaicus (Spyr), Cobitis paludica (Cpal), Luciobarbus spp.--juveniles (Lspp), Luciobarbus sclateri (Lscl), Luciobarbus steidachneri (Lst), Luciobarbus comizo (Lcom), Luciobarbus microcephalus (Lmic), Pseudochondrostoma willkommii (Pwil), Salaria fluviatilis (Sflu), Gambusia holbrooki (Ghol), Ameiurus melas (Amel), Cyprinus carpio (Ccar), Micropterus salmoides (Msal), Lepomis gibbosus (Lgib), Alburnus alburnus (Aalb), Hybrids (Ialb $\times$ Aalb). Non-native species are enclosed by a dashed line.

\subsection{Relative Importance of Environmental Variables and Anthropogenic Disturbance}

Based on the results of the average model, the partition of the variance showed some differences in the relative influence of each variable set among the occurrence and abundance of A. alburnus (Figure 3). The occurrence of A. alburnus was mainly determined by anthropogenic disturbance $(22 \%)$, whereas the abundance of this species showed a proportionally similar influence of the environmental variables (17\%) and anthropogenic disturbance (15\%). The combined effects of the predictive variables were responsible for an important fraction of the variability of both the response variables, particularly for A. alburnus abundance, in which it represents the largest fraction of the explained variance (21\%).

The predictive variables included in the best models of the occurrence and abundance of A. alburnus were very similar and all showed a positive relationship with the response variables (Table 1). Among the environmental models (Env), woody debris, mean water depth and the availability of runs (proportion of run habitats within the stream reach) were the most determinant variables for the occurrence of A. alburnus, all showing maximum values of relative importance. In addition to these environmental variables, the stream order $(R I=0.87)$ and shadow percentage $(R I=1)$ showed a significant influence on the abundance of A. alburnus. Regarding the anthropogenic disturbance models (Dist), the sediment load revealed the highest effect $(R I=1)$ on both the response variables, along with the hydrological regime $(\mathrm{RI}=0.85)$ on the occurrence of $A$. alburnus, and with lentic water bodies $(R I=1)$ on the abundance of this species. The joint effect models (Env + Dist) included most of the environmental and anthropogenic variables present in the "pure" effects models, underlining the determinant effect of the selected variables and their high relative importance in the occurrence and abundance of A. alburnus. 
Table 1. Summary of model selection $(\triangle \mathrm{AIC}<4)$ for predicting the occurrence and abundance of Alburnus alburnus including different sets of variables (model type): environmental (ENV), anthropogenic disturbance (Dist) and combined effects (Env + Dist). For the best model of each type, the Akaike's information criterion (AICc), the difference of AIC between each model and the best model ( $\mathrm{AIC}$ ) and the Akaike weight (wAIC) are registered. Outputs of the averaged coefficients (including the best models summing wAIC >0.9) and the relative importance of the significant predictive variables are also presented.

\begin{tabular}{|c|c|c|c|c|c|c|c|c|c|c|c|c|}
\hline \multicolumn{8}{|c|}{ Best Models } & \multicolumn{4}{|c|}{ Model-Averaged Coefficients } & \multirow[t]{2}{*}{$\begin{array}{l}\text { Relative Variable } \\
\text { Importance (RI) }\end{array}$} \\
\hline Response Variable & Distribution & $\begin{array}{c}\text { Link } \\
\text { Function }\end{array}$ & $\begin{array}{l}\text { Model } \\
\text { Type }\end{array}$ & AICc & $\Delta \mathrm{AIC}$ & wAIC & Predictive Variables & Estimate & $\begin{array}{l}\text { Std. } \\
\text { Error }\end{array}$ & z Value & $\operatorname{Pr}(>$ IzI $)$ & \\
\hline \multirow{9}{*}{$\begin{array}{c}\text { Occurrence } \\
\text { (presence-absence) }\end{array}$} & \multirow{9}{*}{ Binomial } & \multirow{9}{*}{ Logit } & \multirow{3}{*}{ Env } & \multirow{3}{*}{77.400} & \multirow{3}{*}{0} & \multirow{3}{*}{0.620} & Woody debris & 2.184 & 0.791 & 2.763 & 0.006 & 1 \\
\hline & & & & & & & Mean water depth & 7.226 & 2.824 & 2.559 & 0.011 & 1 \\
\hline & & & & & & & Run & 3.003 & 1.139 & 2.635 & 0.008 & 1 \\
\hline & & & \multirow{2}{*}{ Dist } & \multirow{2}{*}{67.490} & \multirow{2}{*}{0} & \multirow{2}{*}{0.080} & Sediment load & 3.524 & 1.033 & 3.411 & 0.001 & 1 \\
\hline & & & & & & & Hydrological regime & 2.821 & 1.180 & 2.390 & 0.017 & 0.85 \\
\hline & & & \multirow{4}{*}{ Env + Dist } & \multirow{4}{*}{59.340} & \multirow{4}{*}{0} & \multirow{4}{*}{0.400} & Sediment load & 3.837 & 1.345 & 2.853 & 0.004 & 1 \\
\hline & & & & & & & Hydrological regime & 3.480 & 1.314 & 2.648 & 0.008 & 1 \\
\hline & & & & & & & Mean water depth & 6.765 & 3.319 & 2.039 & 0.042 & 0.81 \\
\hline & & & & & & & Run & 4.205 & 1.500 & 2.803 & 0.005 & 1 \\
\hline \multirow{12}{*}{$\begin{array}{l}\text { Abundance } \\
\text { (density) }\end{array}$} & \multirow{12}{*}{ Poisson } & \multirow{12}{*}{$\log$} & \multirow{5}{*}{ Env } & \multirow{5}{*}{143.020} & \multirow{5}{*}{0} & \multirow{5}{*}{0.280} & Woody debris & 0.895 & 0.430 & 2.079 & 0.038 & 0.77 \\
\hline & & & & & & & Shadow & 1.635 & 0.527 & 3.103 & 0.002 & 1 \\
\hline & & & & & & & Mean water depth & 2.589 & 1.010 & 2.563 & 0.010 & 0.73 \\
\hline & & & & & & & Run & 1.047 & 0.568 & 1.843 & 0.049 & 0.57 \\
\hline & & & & & & & Stream order & 1.402 & 0.730 & 1.922 & 0.047 & 0.87 \\
\hline & & & \multirow{2}{*}{ Dist } & \multirow{2}{*}{143.140} & \multirow{2}{*}{0} & \multirow{2}{*}{0.190} & Sediment load & 2.129 & 0.514 & 4.141 & $<0.001$ & 1 \\
\hline & & & & & & & Lentic water bodies & 1.281 & 0.354 & 3.622 & $<0.001$ & 1 \\
\hline & & & \multirow{5}{*}{ Env + Dist } & \multirow{5}{*}{123.460} & & & Sediment load & 2.057 & 0.627 & 3.282 & 0.001 & 1 \\
\hline & & & & & & & Lentic water bodies & 1.280 & 0.373 & 3.428 & 0.001 & 1 \\
\hline & & & & & 0 & 0.240 & Shadow & 1.666 & 0.547 & 3.049 & 0.002 & 1 \\
\hline & & & & & & & Mean water depth & 2.020 & 1.141 & 1.769 & 0.050 & 0.44 \\
\hline & & & & & & & Run & 1.163 & 0.610 & 1.906 & 0.048 & 0.55 \\
\hline
\end{tabular}



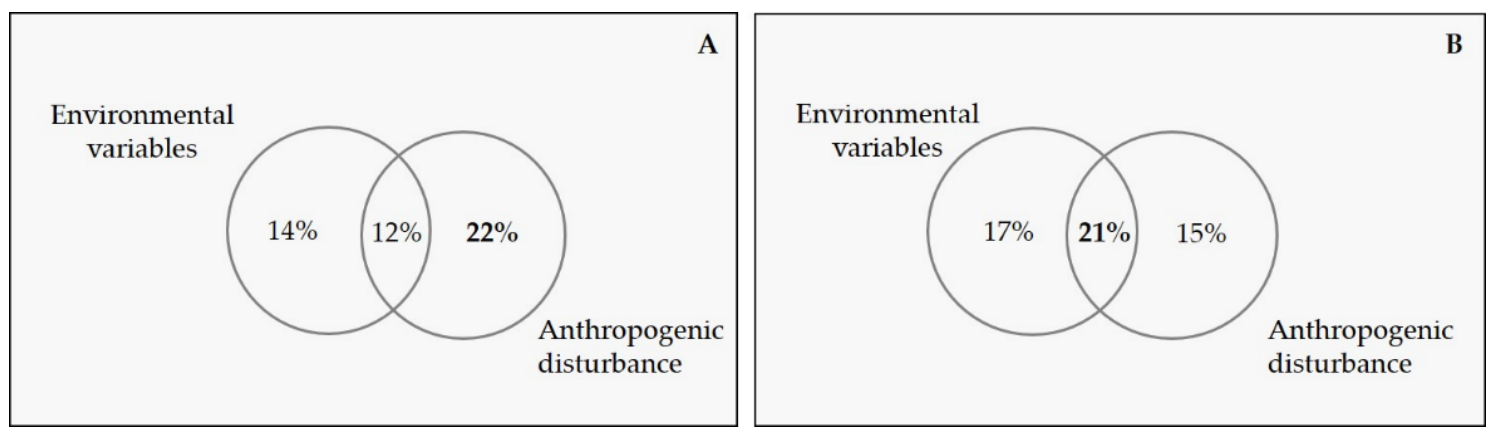

Figure 3. Veen diagrams showing the partition of the variation in the occurrence (presence/absence) (A) and abundance (density, ind $\cdot 100 \mathrm{~m}^{-2}$ ) (B) of Alburnus alburnus explained by environmental and anthropogenic disturbance variables.

\subsection{Spatiotemporal Distribution of A. alburnus}

The analysis of the variability of A. alburnus captures revealed significant differences $(p<0.05)$ in the proportional distribution of the different fish size classes along an upstream-downstream gradient in streams connected with a reservoir in the downstream sector (Figure 4). The results showed that the smallest individuals (smaller than $60 \mathrm{~mm}$ ) where more representative in the upstream and intermediate stream sectors, whereas the larger ones $(150-200 \mathrm{~mm})$ were absent from the upstream sectors and were proportionally more abundant downstream. Individuals from size class $2(60-120 \mathrm{~mm})$ dominated the captures and exhibited a quite similar representativeness within all the stream sectors, whereas those from size class $3(120-150 \mathrm{~mm})$ followed approximately the same pattern of the larger individuals, although they also occurred in the upstream sector, but in very small proportions. Moreover, the distribution of $A$. alburnus size classes also changed significantly over the analyzed periods ( $p<0.05)$, mainly due to the higher proportion of size classes 3 and 4 observed in the spring, when compared to the proportions registered in the other periods (Figure 4).

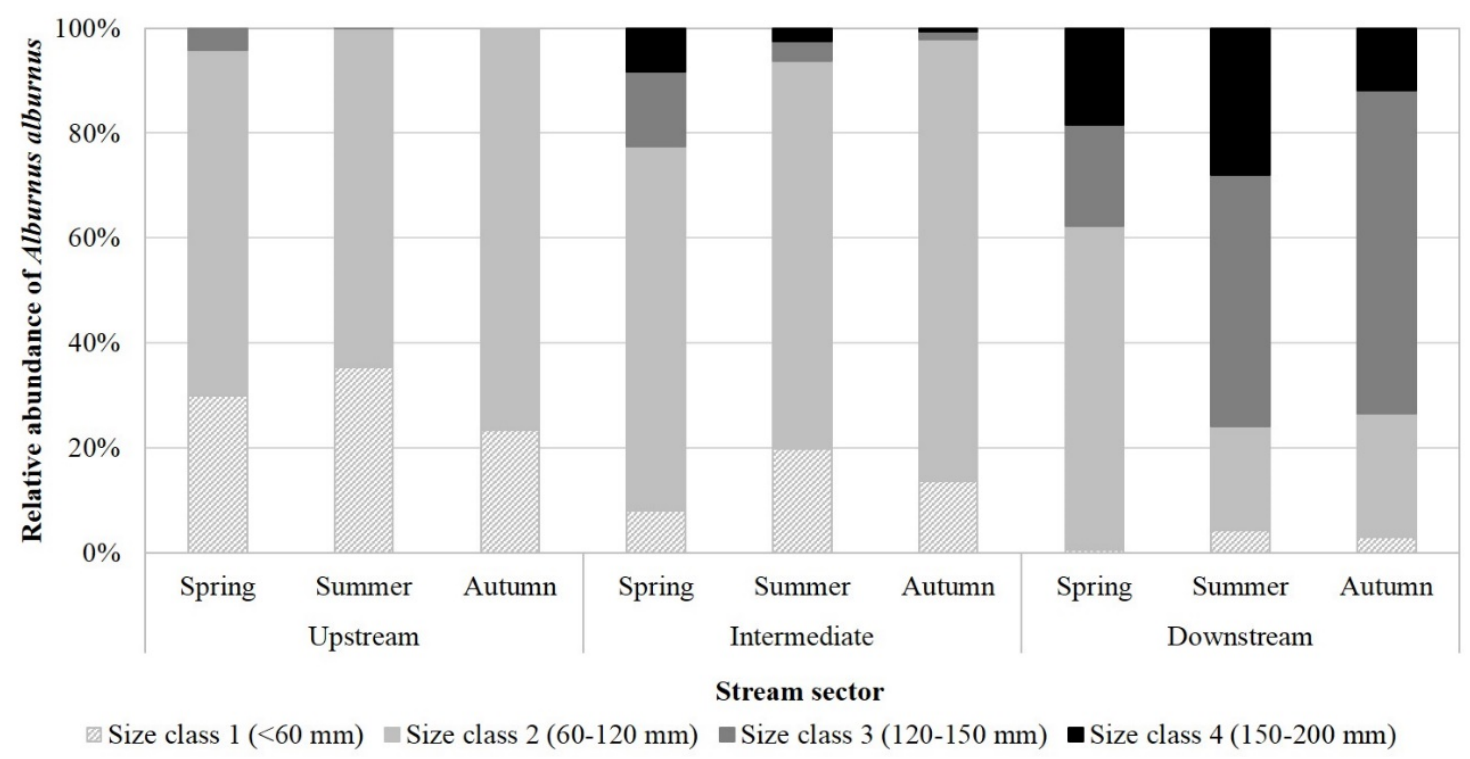

Figure 4. Relative abundance of the size classes defined for Alburnus alburnus in each stream sector over the sampled periods of year.

The comparative analysis of the spatiotemporal variation of the relative abundance of each size class of $A$. alburnus; i.e., their proportional distribution along the period spring-summer-autumn in each river sector (Figure 4)-showed that: (i) class 1 presented a bell-shaped pattern, registering 
the highest proportions in summer and lower values in spring and autumn; (ii) class 2 presented a stable pattern in upstream and intermediate sectors, but a steep decreasing pattern in downstream sectors, exhibiting the highest values in spring, followed by a proportional reduction in summer and autumn; (iii) classes 3 and 4 presented decreasing patterns of the relative abundance in upstream and intermediate sectors, accompanied by a marked proportional increasing pattern in downstream sectors, with the highest values observed in summer and autumn.

\section{Discussion}

\subsection{Patterns and Drivers of Spatial Distribution}

Native species display preferences for fast flowing habitats and show adaptive responses to high flows, which non-native species lack, as they are more adapted to slow flow conditions, therefore displaying preferences for deeper lentic habitats [8]. However, A. alburnus has shown to be the non-native species with the most similar ecological niche compared to native species, especially those with a strong rheophilic character, such as Luciobarbus microcephalus, Pseudochondrostoma willkommii, and Salaria fluviatilis [9], since it was positively related with the availability of run habitats.

The environmental gradient was related to the anthropogenic disturbance gradient, clearly segregating native and non-native species, as the former group was associated with least disturbed sites, whereas the second was more abundant in disturbed ones. Non-native freshwater fish have been frequently documented to succeed in degraded aquatic habitats [69-72]. This is more likely to occur in higher stream orders, as within the southern Mediterranean region, human settlements occur primarily in lowland regions where landscape attributes are more favorable for urban and agriculture development [73], and thus the impact of pollution is usually greater in higher order streams. Disturbed systems and communities may facilitate biological invasions due to the redistribution of space and energy resources, thus opening a "resource gap" for potential invaders [74,75]. On the basis of the resource availability theory, systems with nutrient enrichment and resource availability are more invasible $[74,76]$ by reducing resource limitation and therefore competition. In this perspective, reservoirs are systems conducive to the establishment of potential invaders [16,77] and this is particularly alarming in the Iberian Peninsula, where an increasing construction of reservoirs is being observed $[11,16]$ due to an increasing demand for water. However, anthropogenic disturbance is not a requisite for successful invasion for all introduced species $[72,78,79]$. Whether a disturbance will facilitate an invasion depends on whether the disturbance is natural or anthropogenic [80] and whether the species is favored by the changed conditions [12,81,82].

The occurrence of $A$. alburnus was mainly determined by factors relating to anthropogenic disturbance, whereas the abundance of the species was especially explained by the combined effects of the environmental variables and anthropogenic disturbance, with a proportionally identical influence of the independent effects of these two groups of variables. In any case, the decisive role of the anthropogenic disturbance was evident, consistent with the results obtained for the fish community. Combined, results give support to the "human activity" hypothesis, which argues that human activities facilitate the establishment of non-native species, by disturbing natural landscapes and increasing propagule pressure (i.e., the number of individuals released and the frequency of introductions in a given habitat) [83-85].

Despite their different proportional influences, the environmental variables predicting the occurrence and abundance of $A$. alburnus were very similar, including mean water depth, proportion of runs and percentage of shadow and woody debris, all with positive effects. These hydromorphological local variables are important at the mesohabitat scale, since this species showed a particular preference for medium deep/deep runs and pools, associated with different cover elements, such as woody debris and a high percentage of shadow [86]. Stream order was the only significant regional variable included in the models and it was only included in the "pure" environmental model explaining the abundance of $A$. alburnus. Therefore, the occurrence of $A$. alburnus may be spatially wide but higher 
abundances are more restricted to higher-order reaches, as seen for several non-native species in other studies [21]. This is related to habitat stability, which is higher at lower reaches, as well as close to reservoirs $[6,77,87]$, and is an important environmental factor regulating the colonization and expansion success of invasive species, as they have not evolved in intermittent streams, where water is a limiting resource during part of the year.

Sediment load, alterations of the hydrological regime and the presence of lentic water bodies were the anthropogenic variables determining the occurrence and abundance of A. alburnus. These hydromorphological disturbances are particularly associated with reservoirs, which are known to facilitate the establishment of non-native species [88,89]. Once a population is established in a reservoir, it may facilitate the invasion $[77,88,89]$ and can serve as a stepping-stone for further invasions, a process known as stratified diffusion [88]. Because of their frequent sequential placement in river networks, reservoirs are highly connected to river systems and to other reservoirs, thus, greatly enhancing colonization rates of invasive species [88].

Considering that many non-native species tend to benefit from hydromorphological disturbance associated with reservoirs, an alert program targeting invasive species should be designed at the regional level, linked with the assessment and monitoring of the environmental impact of reservoirs. Further, plans for habitat rehabilitation and anthropogenic pressure reduction should be outlined and implemented, favoring the habitat preferences of native species.

\subsection{Possible Seasonal Movements in Temporary Streams}

There was a significant variability in the proportional distribution of the size classes of A. alburnus along the upstream-downstream gradient in several reservoir tributaries, with the largest individuals occurring predominantly in the downstream river sectors, whereas the smaller ones were proportionally more abundant upstream. Numerous studies reveal variation in the distribution of large and small fish along longitudinal gradients, with small fish generally predominant in shallow upstream or lateral habitats [90-93] and large fish being more abundant in deeper downstream or mid-channel habitats [92,94].

The spatiotemporal distribution of the relative abundance of the various size classes over the analyzed periods suggested that $A$. alburnus may perform seasonal movements between the reservoirs and the upstream sectors of the tributaries (similar to potamodromous migrations of some native cyprinid species). These movements may constitute an excellent adaptation for dispersal, allowing the continued spread of the established population of A. alburnus in the reservoirs. Moreover, migration may be determinant not only as a source of continuing propagule pressure, but also as an important source of genetic variation to the colonizing population, if multiple invasions provide the genetic variation necessary for adaptive evolution [95].

The upstream movements seem to have been performed by individuals larger than $12 \mathrm{~mm}$ (size classes 3 and 4), although the largest size class did not occur in upstream sectors. These movements were apparently performed in the spring, when the proportion of these size classes increased in upstream and intermediate sectors, and were probably associated with the reproductive cycle of A. alburnus [32,96-98]. Similar upstream movements during the spawning season of A. alburnus have also been observed in the native range of distribution of this species [97]. Individuals between $60 \mathrm{~mm}$ and $120 \mathrm{~mm}$ (class 2) were always present in all sectors, maintaining identical proportions. However, the large representativeness of this size class during spring in the downstream sector, compared with the remaining periods of the year, suggested a possible movement of these individuals from the reservoirs to the tributaries. The spatial distribution of the smallest individuals ( $T L<60 \mathrm{~mm}$, size class 1), corresponding to the young-of-the-year cohort, indicated the potential occurrence of recruitment in spring and summer (also in line with the reproductive cycle of the species), particularly in upstream and intermediate river sectors, although they were also observed in downstream sectors. This pattern may be related with the drifting activity of the young-of-the-year [99]. 
Conversely, downstream movements were apparently performed by larger individuals (size classes 3 and 4), as suggested by the proportional reduction of these size classes during the summer in upstream and intermediate sectors, simultaneously with an expressive increase of their relative abundances in downstream sectors in the same period. This may have occurred in response to the reduction of flow (and consequent environmental constraints), which occurs in the intermediate and, especially, upstream sectors during the summer in these temporary streams [1]. As such, larger size classes could move to downstream sectors, possibly due to the proximity to the reservoir, where conditions are more stable [100] and food resources [101] allow them to restore their body condition more quickly after the reproductive period, avoiding a possible mortality [32]. Individuals smaller than $120 \mathrm{~mm}$ (size classes 1 and 2) did not appear to carry out downstream movements from the upstream and intermediate stream sectors, maintaining identical proportional patterns along the year in these two sectors, and without revealing increased proportions in downstream sectors. Like this, they may remain in the pools that persist during the summer and therefore being part of the fish assemblage able to disperse upstream again in the following spring.

The decrease of the relative abundance of size classes 1, 3, and 4 in upstream and intermediate sectors between summer and autumn suggested the probable occurrence of mortality in the summer pools, which may eventually dry up, or present harsh environmental conditions and limiting food resources, promoting the increase of biotic interactions and in which the fish fauna is very vulnerable to predators $[6,7,9]$. This apparent environmental filtering was not so evident in intermediate sectors, since these summer pools are larger and suffer from lower volume reduction throughout the dry period, providing better chances for fish survival during this period [102].

The results suggested that the spread of A. alburnus in these tributaries was mainly driven by the smaller reproductive individuals (size class 2), as well as by the young-of-the-year (size class 1 ) that increase the population abundance annually and then are probably capable to disperse further upstream in the next year, after reaching sexual maturity [98]. Larger individuals (size classes 3, 4) mostly remained in downstream sectors, near or inside the reservoirs, with high water availability and more stable hydrological conditions. This species thus appears to display simultaneously $\mathrm{r}-$ and $\mathrm{K}$ selection life strategies to ensure the invasive success in intermittent streams. The r-selection appears to be adopted by the smallest individuals in the upstream and intermediate sectors, responding opportunistically in order to thrive in an unstable environment. The K-selection is likely to be adopted by the larger individuals in downstream sectors, by staying or returning to a more stable environment, reducing the risks of mortality.

Considering the current alarming decline of the native fish fauna in the Iberian Peninsula and realizing that the number of freshwater fish introductions will continue to increase, river basin conservation and management should be a high priority for intermittent streams. Control strategies for known invasive species should be implemented and, above all, the introduction, and spread, of new, potentially invasive species must be prevented. In this perspective, a risk assessment plan identifying critical and most vulnerable points of the river network should be developed. Moreover, studies addressing the swimming and leaping performance of non-native species, as well as their response to different types of barriers $[103,104]$ could provide fundamental knowledge to outline measures that may limit their dispersal into new areas.

\section{Conclusions}

The occurrence of the invasive A. alburnus in temporary streams from southwestern Iberia was mainly determined by hydromorphological modifications induced by the anthropogenic disturbance, whereas its abundance was mostly explained by the combined effects of the environmental and anthropogenic factors. This species apparently performed seasonal movements along the tributaries of several reservoirs, profiting from these lentic habitats as a stepping-stone for further invasions. This hypothesis advises caution, since observations were based on data from captures rather than on telemetry studies. 
The wide ecological plasticity of A. alburnus enables it to benefit from different types of hydrological and morphological disturbances to guarantee and enhance its invasiveness in Mediterranean intermittent streams, namely by coping with and taking advantage from the natural hydrological variability (associated with the seasonal intermittency of these streams) and by profiting from the anthropogenic hydrological disturbance (induced by reservoirs). These findings provide a sound contribution to fill knowledge gaps on the ecology of the invasive A. alburnus and understand how the interplay between multiple factors may influence its establishment and spread in vulnerable freshwater ecosystems.

Supplementary Materials: The following are available online at http:/ /www.mdpi.com/1424-2818/10/2/47/s1, Figure S1: Length frequency distribution of Alburnus alburnus collected between 2007 and 2016 in the Guadiana and Sado river basins in the south of Portugal $(\mathrm{N}=5021)$.

Author Contributions: P.M. and M.I. conceived the study; all the authors participated in the field work; P.M. analyzed the data; all authors contributed to data interpretation and manuscript preparation.

Funding: This study was primarily funded by the EU Life Programme "Conservation of the Saramugo, Anaecypris hispanica, in the Guadiana basin, Portugal" (LIFE13 NAT/PT/000786).

Acknowledgments: Complementary data were collected in the scope of the project "Climate change and fish communities of Mediterranean-type rivers. Potential impact on the bio-integrity and implications for the ecological status assessment" (CLIMFISH-PTDC/AAC-AMB/102541/2008), funded by the FCT (Fundação para a Ciência e Tecnologia). Special thanks are due to all the colleagues and volunteers who collaborated in the fieldwork, particularly to the members of the partner teams involved in the Life project: LPN (Liga para a Proteção da Natureza), Aqualogus and ICNF (National Institute for the Conservation of Nature and Forests). This manuscript was considerably improved by the constructive comments of three anonymous reviewers and by the editor Pedro Morais.

Conflicts of Interest: The authors declare no conflict of interest. The founding sponsors had no role in the design of the study; in the collection, analyses, or interpretation of data; in the writing of the manuscript, and in the decision to publish the results. 


\section{Appendix A}

Table A1. Description, assessment scale, methods and scoring criteria of the variables used to evaluate the level of anthropogenic disturbance in each sampled site. For land use and hydrological regime, the final score results from a weighted average of the two classes of deviation evaluated.

\begin{tabular}{|c|c|c|c|c|c|}
\hline Variables & Description & Assessment Scale & Score & Criteria & Methods \\
\hline \multirow{8}{*}{ Land use } & \multirow{4}{*}{$\begin{array}{l}\text { Impact of farming/ } \\
\text { forestry practices }\end{array}$} & \multirow{4}{*}{ River segment } & 5 & $\begin{array}{l}>40 \% \text { Agricultural use (intensive agriculture), very severe impact } \\
\text { (rice field) }\end{array}$ & \multirow{8}{*}{$\begin{array}{l}\text { Local expert assessment } \\
\text { complemented with Corine } \\
\text { Land Cover }(2000,2006)^{*}\end{array}$} \\
\hline & & & 4 & $>40 \%$ Strong impact (area with strong forestry, including clearcuts) & \\
\hline & & & 2 & $<40 \%$ Small impact (cork and holm oaks, high-growth forest) & \\
\hline & & & 1 & $<10 \%$ No significant impacts (natural forest and bush) & \\
\hline & \multirow{4}{*}{$\begin{array}{l}\text { Land cover and bankface } \\
\text { characterization }\end{array}$} & \multirow{4}{*}{ Local } & 5 & Irrigated crops and/or high stocking & \\
\hline & & & 3 & $\begin{array}{l}\text { Extensive cultures (e.g., pastures, cereal crops, pine, eucalyptus), } \\
\text { extensive grazing }\end{array}$ & \\
\hline & & & 2 & Cork and holm oaks & \\
\hline & & & 1 & Natural & \\
\hline \multirow{4}{*}{ Urban area } & \multirow{4}{*}{ Impact of urban areas } & \multirow{4}{*}{ River segment } & 5 & Very severe (location near a city with basic sanitation needs) & \multirow{4}{*}{$\begin{array}{l}\text { Local expert assessment } \\
\text { complemented with Corine } \\
\text { Land Cover }(2000,2006)^{*}\end{array}$} \\
\hline & & & 4 & Town & \\
\hline & & & 3 & Village & \\
\hline & & & 1 & Negligible (isolated dwellings) & \\
\hline \multirow{5}{*}{$\begin{array}{l}\text { Riparian } \\
\text { vegetation }\end{array}$} & \multirow{5}{*}{$\begin{array}{l}\text { Deviation from the } \\
\text { natural state of the } \\
\text { riparian zone }\end{array}$} & \multirow{5}{*}{ River segment } & 5 & Lack of riparian shrubs and trees (only the presence of annual plants) & \multirow{5}{*}{ Local expert assessment } \\
\hline & & & 4 & Fragmented vegetation with bushes and/or the presence of reed & \\
\hline & & & 3 & Second replacement step (dominance of dense brushwood) & \\
\hline & & & 2 & $\begin{array}{l}\text { First replacement step (presence of shrub or tree strata with some } \\
\text { level of preservation). }\end{array}$ & \\
\hline & & & 1 & $\begin{array}{l}\text { Potential vegetation (presence of shrub and tree strata according to } \\
\text { the geo-series) }\end{array}$ & \\
\hline
\end{tabular}


Table A1. Cont.

\begin{tabular}{|c|c|c|c|c|c|}
\hline Variables & Description & Assessment Scale & Score & Criteria & Methods \\
\hline \multirow{5}{*}{$\begin{array}{l}\text { Morphological } \\
\text { condition }\end{array}$} & \multirow{5}{*}{$\begin{array}{l}\text { Deviation from the } \\
\text { natural state of the stream } \\
\text { bed and banks }\end{array}$} & \multirow{5}{*}{ Local } & 5 & $\begin{array}{l}\text { Transverse and longitudinal profile of the channel completely changed, } \\
\text { with very few habitats }\end{array}$ & \multirow{5}{*}{ Local expert assessment } \\
\hline & & & 4 & Channelized sector, missing most of the natural habitats & \\
\hline & & & 3 & $\begin{array}{l}\text { Channelized sector, missing some types of natural habitats, but } \\
\text { maintaining much of the shape of the natural channel }\end{array}$ & \\
\hline & & & 2 & Poorly changed sector, close to the natural mosaic of habitats. & \\
\hline & & & 1 & Morphological changes absent or negligible & \\
\hline \multirow{5}{*}{ Sediment load } & \multirow{5}{*}{$\begin{array}{c}\text { Deviation from the } \\
\text { natural sediment load } \\
\text { (both carried in the water } \\
\text { column and deposited on } \\
\text { the riverbed) }\end{array}$} & \multirow{5}{*}{ River segment and local } & 5 & $\begin{array}{l}>75 \% \text { of coarse particles of the stream bed are covered with fine sediments } \\
\text { (sand, silt, clay) }\end{array}$ & \multirow{5}{*}{ Local expert assessment } \\
\hline & & & 4 & $\begin{array}{l}50-75 \% \text { of coarse particles of the stream bed are covered with fine } \\
\text { sediments (sand, silt, clay) }\end{array}$ & \\
\hline & & & 3 & $\begin{array}{l}25-50 \% \text { of coarse particles of the stream bed are covered with fine } \\
\text { sediments (sand, silt, clay) }\end{array}$ & \\
\hline & & & 2 & $\begin{array}{l}5-25 \% \text { of coarse particles of the bed are covered with fine sediments (sand, } \\
\text { silt, clay) }\end{array}$ & \\
\hline & & & 1 & $\begin{array}{l}<5 \% \text { of coarse particles of the stream bed are covered with fine sediments } \\
\qquad \text { (sand, silt, clay) }\end{array}$ & \\
\hline \multirow{10}{*}{$\begin{array}{l}\text { Hydrological } \\
\text { regime }\end{array}$} & \multirow{10}{*}{$\begin{array}{l}\text { Deviation from the } \\
\text { natural hydrological } \\
\text { regime (flow pattern } \\
\text { and/or quantity). } \\
\text { Includes all sources of } \\
\text { hydrologic alteration, } \\
\text { such as significant } \\
\text { water abstraction. }\end{array}$} & \multirow{5}{*}{$\begin{array}{l}\text { Local (classes regarding } \\
\quad \text { flow pattern) }\end{array}$} & 5 & $<50 \%$ and strong deviation from the natural variability of the flow regime & \multirow{10}{*}{$\begin{array}{l}\text { Local expert assessment } \\
\text { complemented with } \\
\text { information from gauging } \\
\text { stations (SNIRH) }\end{array}$} \\
\hline & & & 4 & $\begin{array}{l}<50 \% \text { and moderate deviation from the natural variability of the } \\
\text { flow regime }\end{array}$ & \\
\hline & & & 3 & $>50 \%$ and duration of flood periods close to the natural & \\
\hline & & & 2 & $>75 \%$ and duration of flood periods close to the natural & \\
\hline & & & 1 & $>90 \%$ and normal duration of natural flood periods & \\
\hline & & \multirow{5}{*}{$\begin{array}{l}\text { Local (classes regarding } \\
\text { mean annual discharge) }\end{array}$} & 5 & $<10 \%$ of mean annual discharge & \\
\hline & & & 4 & $<15 \%$ of mean annual discharge & \\
\hline & & & 3 & $>15 \%$ of mean annual discharge & \\
\hline & & & 2 & $>30 \%$ of mean annual discharge & \\
\hline & & & 1 & $>90 \%$ of mean annual discharge & \\
\hline
\end{tabular}


Table A1. Cont.

\begin{tabular}{|c|c|c|c|c|c|}
\hline Variables & Description & Assessment Scale & Score & Criteria & Methods \\
\hline \multirow{5}{*}{$\begin{array}{l}\text { Toxic and } \\
\text { acidification } \\
\text { levels }\end{array}$} & \multirow{5}{*}{$\begin{array}{l}\text { Deviation from the natural state } \\
\text { of toxicity conditions, including } \\
\text { acidification, and oxygen levels }\end{array}$} & \multirow{5}{*}{ Local } & 5 & $\begin{array}{l}\text { Constant for long periods (months) or frequent occurrence of strong } \\
\text { deviations from natural conditions (e.g., } \mathrm{pH}<5.0, \mathrm{DO}<30 \% \text { ) }\end{array}$ & \multirow{5}{*}{$\begin{array}{l}\text { Local expert assessment } \\
\text { complemented with information } \\
\text { from gauging stations (SNIRH) }\end{array}$} \\
\hline & & & 4 & $\begin{array}{l}\text { Constant for long periods (months) or frequent occurrence of strong } \\
\text { deviations from natural conditions (e.g., } \mathrm{pH}<5.5, \mathrm{DO}<30-50 \% \text { ) }\end{array}$ & \\
\hline & & & 3 & $\begin{array}{c}\text { Occasional deviations (single measurements or episodic) in relation } \\
\text { to natural conditions (e.g., } \mathrm{pH}<5.5, \mathrm{DO}<30-50 \% \text { ) }\end{array}$ & \\
\hline & & & 2 & $\begin{array}{c}\text { Occasional deviations (single measurements or episodic) in relation } \\
\text { to natural conditions (e.g., } \mathrm{pH}<6.0 \text { ) }\end{array}$ & \\
\hline & & & 1 & Conditions within the normal range of variation & \\
\hline \multirow{5}{*}{$\begin{array}{l}\text { Organic and } \\
\text { nutrient loads }\end{array}$} & \multirow{5}{*}{$\begin{array}{c}\text { Deviation from the normal } \\
\text { values of BOD, COD, } \\
\text { ammonium, nitrate, } \\
\text { and phosphate concentrations }\end{array}$} & \multirow{5}{*}{ Local } & 5 & $>20 \%$ of values in classes $\mathrm{D}$ or $\mathrm{E}$ & \multirow{5}{*}{$\begin{array}{l}\text { SNIRH ** (classification of water } \\
\text { quality for multiple uses, } \\
\text { according to the guidelines from } \\
\text { the Water National Institute), } \\
\text { complemented with local } \\
\text { expert assessment }\end{array}$} \\
\hline & & & 4 & $>10 \%$ of values in classes $\mathrm{D}$ or $\mathrm{E}$ & \\
\hline & & & 3 & $>10 \%$ of values in class $\mathrm{C}$ & \\
\hline & & & 2 & No obvious or too small signs of eutrophication and organic loading & \\
\hline & & & 1 & No signs of eutrophication and organic loading & \\
\hline \multirow{5}{*}{$\begin{array}{l}\text { Artificial lentic } \\
\text { water bodies }\end{array}$} & \multirow{5}{*}{$\begin{array}{l}\text { Impact related to the presence } \\
\text { of artificial lentic water bodies } \\
\text { upstream and/or downstream } \\
\text { of the site (upstream change in } \\
\text { thermal and flow regimes; } \\
\text { downstream invasion by exotic } \\
\text { species of lentic character) }\end{array}$} & \multirow{5}{*}{ Local } & 5 & $\begin{array}{l}\text { Local immediately downstream of a large reservoir or within the } \\
\text { influence area of its backwater }\end{array}$ & \multirow{5}{*}{$\begin{array}{l}\text { SNIRH } * * \text { and } \\
\text { available cartography }\end{array}$} \\
\hline & & & 4 & $\begin{array}{l}\text { Local immediately downstream of a mini-hydro or within the } \\
\text { influence area of its backwater }\end{array}$ & \\
\hline & & & 3 & $\begin{array}{l}\text { Local downstream of a massive standing water body or within the } \\
\text { influence area of the reservoir }\end{array}$ & \\
\hline & & & 2 & $\begin{array}{l}\text { Local downstream of a mini-hydro or within the influence area of } \\
\text { its backwater }\end{array}$ & \\
\hline & & & 1 & No influence of reservoirs & \\
\hline \multirow{5}{*}{ Connectivity } & \multirow{5}{*}{$\begin{array}{l}\text { Impact of artificial barriers to } \\
\text { fish migration }\end{array}$} & \multirow{5}{*}{ River basin and segment } & 5 & Permanent artificial barrier & \multirow{5}{*}{$\begin{array}{c}\text { SNIRH }{ }^{* *} \text {, available cartography, } \\
\text { documental data and local } \\
\text { expert assessment }\end{array}$} \\
\hline & & & 4 & Occasional passage of some species & \\
\hline & & & 3 & Passage of certain species or only in certain years & \\
\hline & & & 2 & Passage of most species in most years & \\
\hline & & & 1 & No barriers or existence of an effective pass-through device & \\
\hline
\end{tabular}




\section{References}

1. Gasith, A.; Resh, V.H. Streams in Mediterranean climate regions: Abiotic influences and biotic responses to predictable seasonal events. Annu. Rev. Ecol. Syst. 1999, 30, 51-81. [CrossRef]

2. Poff, N.L.; Ward, J.V. Implications of streamflow variability and predictability for lotic community structure: A regional analysis of streamflow patterns. Can. J. Fish. Aquat. Sci. 1989, 46, 1805-1818. [CrossRef]

3. Poff, N.L.; Allan, J.D. Functional organization of stream fish assemblages in relation to hydrologic variability. Ecology 1995, 76, 606-627. [CrossRef]

4. Richter, B.D.; Mathews, R.; Harrison, D.L.; Wigington, R. Ecologically sustainable water management: Managing river flows for ecological integrity. Ecol. Appl. 2003, 13, 206-224. [CrossRef]

5. Marchetti, M.P.; Moyle, P.B. Effects of flow regime and habitat structure on fish assemblages in a regulated California stream. Ecol. Appl. 2001, 11, 530-539. [CrossRef]

6. Magalhães, M.F.; Batalha, D.C.; Collares-Pereira, M.J. Gradients in stream fish assemblages across a Mediterranean landscape: Contributions of environmental factors and spatial structure. Freshw. Biol. 2002, 47, 1015-1031. [CrossRef]

7. Magalhães, M.F.; Beja, P.; Schlosser, I.J.; Collares-Pereira, M.J. Effects of multi-year droughts on fish assemblages of seasonally drying Mediterranean streams. Freshw. Biol. 2007, 52, 1494-1510. [CrossRef]

8. Bernardo, J.M.; Ilhéu, M.; Matono, P.; Costa, A.M. Interannual variation of fish assemblage structure in a Mediterranean river: Implications of streamflow on the dominance of native or exotic species. River Res. Appl. 2003, 19, 1-12. [CrossRef]

9. Ilhéu, M. Patterns of Habitat Use by Freshwater Fishes in Mediterranean Rivers. Ph.D. Thesis, University of Évora, Évora, Portugal, 2004.

10. Economidis, P.S. Endangered freshwater fishes of Greece. Biol. Conserv. 1995, 72, 201-211. [CrossRef]

11. Collares-Pereira, M.J.; Cowx, I.G.; Ribeiro, F.; Rodrigues, J.A.; Rogado, L. Threats imposed by water resources development schemes on the conservation of the endangered fish species in the Guadiana River, Portugal. Fish. Manag. Ecol. 2000, 7, 167-178. [CrossRef]

12. Moyle, P.B.; Light, T. Biological invasions of freshwater: Empirical rules and assembly theory. Biol. Conserv. 1996, 78, 149-161. [CrossRef]

13. Bunn, S.E.; Arthington, A.H. Basic principles and ecological consequences of altered flow regimes for aquatic biodiversity. Environ. Manage. 2002, 30, 492-507. [CrossRef] [PubMed]

14. Kennard, M.J.; Arthington, A.H.; Pusey, B.J.; Harch, B.D. Are alien fish a reliable indicator of river health? Freshw. Biol. 2005, 50, 174-193. [CrossRef]

15. Gehrke, P.C.; Harris, J.H. Regional-scale effects of flow regulation on lowland riverine fish communities in New South Wales, Australia. Regul. River 2001, 17, 369-391. [CrossRef]

16. Filipe, A.F.; Marques, T.; Seabra, S.; Tiago, P.; Ribeiro, F.; Moreira da Costa, L.; Cowx, I.G.; Collares-Pereira, M.J. Selection of priority areas for fish conservation in Guadiana River Basin, Iberian Peninsula. Conserv. Biol. 2004, 18, 189-200. [CrossRef]

17. Leprieur, F.; Beauchard, O.; Blanchet, S.; Oberdorff, T.; Brosse, S. Fish invasions in the world's river systems: When natural processes are blurred by human activities. PLoS Biol. 2008, 6, e28. [CrossRef]

18. Marr, S.M.; Marchetti, M.P.; Olden, J.D.; García-Berthou, E.; Morgan, D.L.; Arismendi, I.; Day, J.A.; Griffiths, C.L.; Skelton, P.H. Freshwater fish introductions in mediterranean-climate regions: Are there commonalities in the conservation problem? Divers. Distrib. 2010, 16, 606-619. [CrossRef]

19. Rahel, F.J. Homogenization of fish faunas across the United States. Science 2000, 288, 854-856. [CrossRef] [PubMed]

20. Marr, S.M.; Olden, J.D.; Leprieur, F.; Arismendi, I.; Ćaleta, M.; Morgan, D.L.; Nocita, A.; Šanda, R.; Tarkan, A.S.; García-Berthou, E. A global assessment of freshwater fish introductions in mediterranean-climate regions. Hydrobiologia 2013, 719, 317-329. [CrossRef]

21. Hermoso, V.; Clavero, M.; Blanco-Garrido, F.; Prenda, J. Invasive species and habitat degradation in Iberian streams: An analysis of their role in freshwater fish diversity loss. Ecol. Appl. 2011, 21, 175-188. [CrossRef] [PubMed]

22. Cucherousset, J.; Olden, J.D. Ecological Impacts of Nonnative Freshwater Fishes. Fisheries 2011, 36, $215-230$. [CrossRef] 
23. Leunda, P.M. Impacts of non-native fishes on Iberian freshwater ichthyofauna: Current knowledge and gaps. Aquat. Invasions 2010, 5, 239-262. [CrossRef]

24. Elvira, B.; Almodóvar, A. Freshwater fish introductions in Spain: Facts and figures at the beginning of the 21st century. J. Fish Biol. 2001, 59, 323-331. [CrossRef]

25. Ribeiro, F.; Collares-Pereira, M.J.; Moyle, P.B. Non-native fish in the fresh waters of Portugal, Azores and Madeira Islands: A growing threat to aquatic biodiversity. Fish. Manag. Ecol. 2009, 16, 255-264. [CrossRef]

26. Freyhof, J.; Kottelat, M. Alburnus alburnus. The IUCN Red List of Threatened Species. 2008. Available online: http:/ / dx.doi.org/10.2305/IUCN.UK.2008.RLTS.T789A13079658.en (accessed on 2 October 2017).

27. Elvira, B. Native and exotic freshwater fishes in Spanish river basins. Freshw. Biol. 1995, 33, $103-108$. [CrossRef]

28. Pérez-Bote, J.L.; Roso, R.; Pula, H.J.; Díaz, F.; López, M.T. Primeras citas de la lucioperca, Sander (= Stizostedion) lucioperca (Linnaeus, 1758) y del alburno, Alburnus alburnus (Linnaeus, 1758) en las cuencas extremeñas de los ríos Tajo y Guadiana, SO de la Península Ibérica. Ann. Biol. 2004, 26, 93-100.

29. Velasco, J.C. Peces. In Guía de los Peces, Anfibios, Reptiles y Mamíferos de Castilla y León; Velasco, J.C., Lizana, M., Román, J., Delibes, M., Fernández, J., Eds.; Náyade: Medina del Campo, Spain, 2005.

30. Vinyoles, D.; Robalo, J.I.; de Sostoa, A.; Almodóvar, A.M.; Elvira, B.; Nicola, G.G.; Fernández-Delgado, C.; Santos, S.; Doadrio, I.; Sardá-Palomera, F.; et al. Spread of the alien bleak Alburnus alburnus (Linnaeus, 1758) (Actinopterygii, Cyprinidae) in the Iberian Peninsula: The role of reservoirs. Graellsia 2007, 63, 101-110. [CrossRef]

31. Brabrand, A. Distribution of fish and food of roach Rutilus rutilus, bleak Alburnus alburnus, bream Abramis brama and ruffe Acerina cernua in Lake Vansjo Southeast Norway. Fauna 1983, 36, 57-64.

32. Almeida, D.; Stefanoudis, P.V.; Fletcher, D.H.; Rangel, C.; da Silva, E. Population traits of invasive bleak Alburnus alburnus between different habitats in Iberian fresh waters. Limnologica 2014, 46, 70-76. [CrossRef]

33. Masó, G.; Latorre, D.; Tarkan, A.S.; Vila-Gispert, A.; Almeida, D. Inter-population plasticity in growth and reproduction of invasive bleak, Alburnus alburnus (Cyprinidae, Actinopterygii), in northeastern Iberian Peninsula. Folia Zool. 2016, 65, 10-14. [CrossRef]

34. Myers, J.H.; Simberloff, D.A.; Kuris, A.M.; Carey, J. Eradication revisited: Dealing with exotic species. Trends Ecol. Evol. 2000, 15, 316-320. [CrossRef]

35. Agência Portuguesa Do Ambiente. Atlas do Ambiente Digital. Available online: http://sniambapambiente. pt/ (accessed on 27 October 2017).

36. Miranda, P.; Coelho, F.S.; Tomé, A.R.; Valente, M.A. 20th century Portuguese climate and climate scenarios. In Climate Change in Portugal: Scenarios, Impacts and Adaptation Measures-SIAM Project; Santos, F.D., Forbes, K., Moniz, R., Eds.; Gradiva: Lisboa, Portugal, 2002; pp. 23-84. Available online: http:/ / www.siam.fc.ul.pt/SIAM_Book (accessed on 20 September 2017).

37. WWF Mediterranean Programme. Water Footprint in Portugal-An Analysis of the External Footprint and Consumption; Technical Report; WWF Mediterranean Programme. 2011. Available online: www.wwf.pt (accessed on 20 September 2017).

38. Matono, P.; Sousa, D.; Ilheu, M. Effects of land use intensification on fish assemblages in Mediterranean climate streams. Environ. Manage. 2013, 52, 1213-1229. [CrossRef] [PubMed]

39. Sistema Nacional de Informação de Recursos Hídricos. Available online: http://snirh.pt (accessed on 20 September 2017).

40. Allan, J.D. Landscapes and riverscapes: The influence of land use on stream ecosystems. Annu. Rev. Ecol. Evol. Syst. 2004, 35, 257-284. [CrossRef]

41. Cabral, M.J.; Almeida, J.; Almeida, P.R.; Dellinger, T.R.; Ferrand de Almeida, N.; Oliveira, M.E.; Palmeirim, J.M.; Queiroz, A.I.; Rogado, L.; Santos-Reis, M. Livro Vermelho dos Vertebrados de Portugal; Instituto da Conservação da Natureza: Lisboa, Portugal, 2005.

42. Smith, K.G.; Darwall, W.R.T. The Status and Distribution of Freshwater Fish Endemic to the Mediterranean Basin; IUCN: Gland, Switzerland; Cambridge, UK, 2006.

43. Hermoso, V.; Clavero, M. Threatening processes and conservation management of endemic freshwater fish in the Mediterranean basin: A review. Mar. Freshw. Res. 2011, 62, 244-254. [CrossRef] 
44. Ilhéu, M.; Matono, P.; Bernardo, J.M.; Costa, A.M.; Miguens, F.; Ribeiro, L.; Oliveira, R.P. Alterações Climáticas e Comunidades Piscícolas de Cursos de Tipo Mediterrânico. Impacte Potencial na Bio-Integridade e Implicações na Avaliação do Estado Ecológico; Relatório Final de Projeto PTDC/AAC-AMB/102541/2008; Universidade de Évora: Évora, Portugal, 2014.

45. Inag, I.P. Manual Para a Avaliação Biológica da Qualidade da Água em Sistemas Fluviais Segundo a Directiva Quadro da Água Protocolo de Amostragem e Análise Para a Fauna Piscícola; Ministério do Ambiente, do Ordenamento do Território e do Desenvolvimento Regional, Instituto da Água, I.P: Lisboa, Portugal, 2008.

46. European Commission. Directive 2000/60/EC of the European Parliament and of the Council of 23 October 2000. Establishing a Framework for Community Action in the Field of Water Policy; Official Journal of the European Communities L327. 2000. Available online: http:/ / ec.europa.eu/environment/water/waterframework/index_en.html (accessed on 8 June 2016).

47. European Union. Directive 2010/63/EU of The European Parliament and of the Council of 22 September 2010 on the Protection of Animals used for Scientific Purposes. Off. J. Eur. Union 2010, L276, 33-79.

48. Giller, P.S.; Malmqvist, B. The Biology of Streams and Rivers; Oxford University Press: New York, NY, USA, 1998.

49. Fame Group. Development, Evaluation E Implementation of a Standardised Fish-based Assessment Method for the Ecological Status of European Rivers-A Contribution to the Water Framework Directive; Final Report, Scientific Achievements (Sections 5 \& 6) (Co-Ordinator: Stefan Schmutz); Institute for Hydrobiology and Aquatic Ecosystem Management, University of Natural Resources and Applied Life Sciences: Vienna, Austria, 2004; Available online: http:/ / fame.boku.ac.at (accessed on 8 June 2016).

50. Matono, P.; Bernardo, J.M.; Costa, A.M.; Ilhéu, M. Fish response to anthropogenic pressures in temporary streams: The importance of environmental drivers. River Res. Appl. 2014, 30, 1281-1295. [CrossRef]

51. CIS-WFD-Guidance on Establishing Reference Conditions and Ecological Status Class Boundaries for Inland Surface Waters. Final Version, EU Common Implementation Strategy for the Water Framework Directive. 2003. Available online: http:/ / ec.europa.eu/environment/water/water-framework/index_en. html (accessed on 8 June 2016).

52. Lorenzen, C.J. Determination of chlorophyll and pheopigments: Spectrophotometric equations. Limnol. Oceanogr. 1967, 12, 343-346. [CrossRef]

53. Clesceri, L.S.; Greenberg, A.E.; Eaton, A.D. Standard Methods for the Examination of Water and Wastewater, 20th ed.; American Public Health Association, American Water Works Association, Water Environmental Federation: Washington, DC, USA, 1998.

54. Jongman, R.H.G.; ter Braak, C.J.F.; van Tongeren, O.F.R. Data Analysis in Community and Landscape Ecology; Pudoc: Wageningen, The Netherlands, 1987.

55. Ter Braak, C.J.F.; Smilauer, P. CANOCO Reference Manual and User's Guide to Canoco for Windows: Software for Canonical Community Ordination (Version 4.0); Microcomputer Power: Ithaca, NY, USA, 1998.

56. Borcard, D.; Legendre, P.; Drapeau, P. Partialling out the spatial component of ecological variation. Ecology 1992, 73, 1045-1055. [CrossRef]

57. Burnham, K.P.; Anderson, D.R. Model Selection and Multimodel Inference: A Practical Information-Theoretic Approach, 2nd ed.; Springer: New York, NY, USA, 2002.

58. Barbosa, A.M.; Brown, J.A.; Jiménez-Valverde, A.; Real, R. modEvA—An R Package for Model Evaluation and Analysis; R Package Version 0.1. 2014. Available online: http:/ / modeva.r-forge.r-project.org/ (accessed on 5 July 2017).

59. Zuur, A.; Ieno, E.N.; Walker, N.; Saveliev, A.A.; Smith, G.M. Mixed Effects Models and Extensions in Ecology with R; Springer: New York, NY, USA, 2009.

60. Kottelat, M. European Freshwater Fishes; Slovak Academy of Sciences: Štefánikova, Slovakia, 1997.

61. Bhattacharya, C.G. A simple method of resolution of a distribution into Gaussian components. Biometrics 1967, 23, 115-135. [CrossRef] [PubMed]

62. Sturges, H.A. The choice of a class interval. J. Am. Stat. Assoc. 1926, 21, 65-66. [CrossRef]

63. Scott, D.W. Sturges' rule. WIREs Comp. Stat. 2009, 1, 303-306. [CrossRef]

64. Anderson, M.J. A new method for non-parametric multivariate analysis of variance. Austral Ecol. 2001, 26, 32-46. [CrossRef]

65. R Core Team. R: A Language and Environment for Statistical Computing; Version 3.4.1; R Foundation for Statistical Computing: Vienna, Austria, 2017; Available online: http:/ / www.R-project.org/ (accessed on 5 July 2017). 
66. Fox, J.; Weisberg, S. An R Companion to Applied Regression, 2nd ed.; Sage: Thousand Oaks, CA, USA, 2011; Available online: http:/ / socserv.socsci.mcmaster.ca/jfox/Books/Companion (accessed on 5 July 2017).

67. Barton, K. MuMIn: Multi-model Inference; R Package Version 1.4. 2017. Available online: http://r-forge.rproject.org/projects/mumin/ (accessed on 5 July 2017).

68. Legendre, P.; Legendre, L. Numerical Ecology, 2nd ed.; Elsevier: Amsterdam, The Netherlands, 1998.

69. Arthington, A.H.; Hamlet, S.; Bluhdorn, D.R. The role of habitat disturbance in the establishment of introduced warm-water fishes in Australia. In Introduced and Translocated Fishes and Their Ecological Effect. Bureau of Rural Resources Proceedings No. 8; Pollard, D.A., Ed.; Australian Government Publishing Service: Canberra, Australia, 1990; pp. 61-66.

70. Ross, R.; Lellis, W.A.; Bennett, R.M.; Johnson, C.S. Landscape determinants of non-indigenous fish invasions. Biol. Invasions 2001, 3, 347-361. [CrossRef]

71. Meador, M.R.; Brown, L.R.; Short, T. Relations between introduced fish and environmental Conditions at large geographic scales. Ecol. Indic. 2003, 3, 81-92. [CrossRef]

72. Ilhéu, M.; Matono, P.; Bernardo, J.M. Invasibility of Mediterranean-Climate Rivers by Non-Native Fish: The Importance of Environmental Drivers and Human Pressures. PLoS ONE 2014, 9, e109694. [CrossRef] [PubMed]

73. Lepart, J.; Debussche, M. Human Impact on Landscape Patterning: Mediterranean Examples. In Landscape Boundaries, Ecological Studies (Analysis and Synthesis); Hansen, A.J., di Castri, F., Eds.; Springer: New York, NY, USA, 1992; Volume 92, pp. 76-106.

74. Davis, M.; Grime, J.; Thompson, K. Fluctuating resources in plant communities: A general theory of invasibility. J. Ecol. 2000, 88, 528-534. [CrossRef]

75. Belote, R.T.; Jones, R.H.; Hood, S.M.; Wender, B. Diversity-invasibility across an experimental disturbance gradient in Appalachian forests. Ecology 2008, 89, 183-192. [CrossRef] [PubMed]

76. González, A.L.; Kominoski, J.S.; Danger, M.; Ishida, S.; Iwai, N.; Rubach, A. Can ecological stoichiometry help explain patterns of biological invasions? Oikos 2010, 119, 779-790. [CrossRef]

77. Clavero, M.; Blanco-Garrido, F.; Prenda, J. Fish fauna in Iberian Mediterranean basins: Biodiversity, introduced species and damming impacts. Aquat. Conserv. 2004, 14, 575-585. [CrossRef]

78. Niemela, J.; Spence, J.R. Distribution and abundance of an exotic ground beetle (Carabidae): A test of community impact. Oikos 1991, 62, 351-359. [CrossRef]

79. Townsend, C.R. Invasion biology and ecological impacts of brown trout Salmo trutta in New Zealand. Biol. Conserv. 1996, 78, 13-22. [CrossRef]

80. McIntosh, A.R. Habitat and size-related variations in exotic trout impacts on native galaxiid fishes in New Zealand streams. Can. J. Fish. Aquat. Sci. 2000, 57, 2140-2151. [CrossRef]

81. Baltz, D.M.; Moyle, P.B. Invasion resistance to introduced species by a native assemblage of California stream fishes. Ecol. Appl. 1993, 3, 246-255. [CrossRef] [PubMed]

82. Townsend, C.R. Individual, population, community and ecosystem consequences of a fish invader in New Zealand streams. Conserv. Biol. 2003, 17, 38-47. [CrossRef]

83. Chown, S.L.; Gremmen, N.J.M.; Gaston, K.J. Ecological biogeography of southern ocean islands: Species-area relationships, human impacts, and conservation. Am. Nat. 1998, 152, 562-575. [CrossRef] [PubMed]

84. Taylor, B.W.; Irwin, R.E. Linking economic activities to the distribution of exotic plants. Proc. Natl. Acad. Sci. USA 2004, 101, 17725-17730. [CrossRef] [PubMed]

85. Meyerson, L.A.; Mooney, H.A. Invasive alien species in an era of globalization. Front. Ecol. Environ. 2007, 5, 199-208. [CrossRef]

86. Matono, P.; da Silva, J.; Bernardo, J.M.; Costa, A.M.; Ilhéu, M. Patterns of Habitat Use of the Endangered Saramugo, Anaecypris hispanica, and the Invasive Bleak, Alburnus alburnus in Mediterranean Temporary Rivers: Potential Negative Interactions. Unpublished work. 2018.

87. Godinho, F.N.; Ferreira, M.T.; Cortes, R.V. Composition and spatial organization of fish assemblages in the lower Guadiana basin, southern Iberia. Ecol. Freshw. Fish 1997, 6, 134-143. [CrossRef]

88. Havel, J.E.; Lee, C.E.; Vander Zanden, M.J. Do reservoirs facilitate invasions into landscapes? BioScience 2005, 55, 518-525. [CrossRef]

89. Johnson, P.T.J.; Olden, J.D.; Vander Zanden, M.J. Dam invaders: Impoundments facilitate biological invasions into freshwaters. Front. Ecol. Environ. 2008, 6, 357-363. [CrossRef] 
90. Welcomme, R.L. River Fisheries; FAO Technical Paper 262; Food and Agriculture Organization of the United Nations: Rome, Italy, 1985.

91. Power, M.E. Predator avoidance by grazing fishes in temperate and tropical streams: Importance of stream depth and prey size. In Predation: Direct and Indirect Impacts on Aquatic Communities; Kerfoot, W.C., Sih, A., Eds.; University of New England Press: Hanover, NH, USA, 1987; pp. 333-353.

92. Schlosser, I.J. A conceptual framework for fish communities in small warmwater streams. In Community and Evolutionary Ecology of North American Stream Fishes; Matthews, W.J., Heins, D.C., Eds.; University of Oklahoma Press: Norman, OK, USA, 1987; pp. 17-24.

93. Moore, K.M.S.; Gregory, S.V. Summer habitat utilization and ecology of cutthroat trout fry (Salmo clarki) in Cascade Mountain streams. Can. J. Fish. Aquat. Sci. 1988, 45, 1921-1930. [CrossRef]

94. Pires, A.M.; Cowx, I.G.; Coelho, M.M. Seasonal changes in fish community structure of intermittent streams in the middle reaches of the Guadiana basin, Portugal. J. Fish Biol. 1999, 54, 235-249. [CrossRef]

95. Sakai, A.K.; Allendorf, F.W.; Holt, J.S.; Lodge, D.M.; Molofsky, J.; With, K.A.; Baughman, S.; Cabin, R.J.; Cohen, J.E.; Ellstrand, N.C.; et al. The population biology of invasive species. Annu. Rev. Ecol. Syst. 2001, 32, 305-332. [CrossRef]

96. Hladík, M.; Kubecka, J. Fish migration between a temperate reservoir and its main tributary. Hydrobiologia 2003, 504, 251-266. [CrossRef]

97. Kotusz, J.; Witkowski, A.; Baran, M.; Błachuta, J. Fish migrations in a large lowland river (Odra R., Poland) based on fish pass observations. Folia Zool. 2006, 55, 386-398.

98. Ilhéu, M.; Matono, P.; da Silva, J.; Sousa-Santos, C.; Venade, D.; Emídio, M.; Jines, C.; Bernardo, J.M.; Costa, A.M.; Sousa, D.; et al. Ação A4-Estudo Sobre o Impacte de Alburmo (Alburnus alburnus) Sobre as Populações de Saramugo; Relatório Final da Ação A4 do Projeto LIFE 13 NAT/PT/000786; Universidade de Évora: Évora, Portugal, 2016.

99. Reichard, M.; Jurajda, P.; Ondračkovaá, M. Interannual variability in seasonal dynamics and species composition of drifting young-of-the-year fishes in two European lowland rivers. J. Fish Biol. 2002, 60, 87-101. [CrossRef]

100. Wetzel, R.G. Limnology: Lake and River Ecosystems; Elsevier Academic Press: London, UK, 2001.

101. Vøllestad, L.A. Resource partitioning of roach Rutilus rutilus and bleak Alburnus alburnus in two eutrophic lakes in SE Norway. Ecography 1985, 8, 88-92. [CrossRef]

102. Taylor, C.M.; Warren, M.L. Dynamics in species composition of stream fish assemblages: Environmental variability and nested subsets. Ecology 2000, 82, 2320-2330. [CrossRef]

103. Bernardo, J.M.; Costa, A.M.; Matono, P.; da Silva, J. Ação A5-Estudo de Mecanismos de Controlo de Dispersão de Alburno: Barreiras à Progressão de Alburno; Relatório Final da Ação A5 do Projeto LIFE 13 NAT/PT/000786; Universidade de Évora: Évora, Portugal, 2017.

104. Starrs, T.; Starrs, D.; Lintermans, M.; Fulton, C.J. Assessing upstream invasion risk in alien freshwater fishes based on intrinsic variations in swimming speed performance. Ecol. Freshw. Fish 2017, 26, 75-86. [CrossRef]

105. Caetano, M.; Nunes, V.; Nunes, A. CORINE Land Cover 2006 for Continental Portugal; Instituto Geográfico Português: Lisboa, Portugal, 2009.

(C) 2018 by the authors. Licensee MDPI, Basel, Switzerland. This article is an open access article distributed under the terms and conditions of the Creative Commons Attribution (CC BY) license (http:// creativecommons.org/licenses/by/4.0/). 